\title{
СКРИВЕНИ КУРИКУЛУМ У НАСТАВИ ШПАНСКОГ КАО СТРАНОГ ЈЕЗИКА У СРБИЈИ, СА ПОСЕБНИМ ОСВРТОМ НА РОДНО ОСЕТЉИВ ПРИСТУП У УЧИОНИЦИ: СТАВОВИ НАСТАВНОГ КАДРА
}

Образовне институције преносе доминантне друштвене идеологије, те је важно заузети критички став према ономе што се дешава у учионици. Непходно је анализирати како експлицитни тако и имплицитни курикулум. Из тог разлога одлучили смо се за анализу мишљења и ставова наставника и наставница шпанског као страног језика у Србији према појму скривеног курикулума и начина на који га дефинишу са посебним освртом на родно сензитиван приступ у настави. Испитаницима и испитаницама електронским путем прослеђен је упитник. Након квалитативне анализе дошли смо до резултата који указују на то да наставни кадар на различите начине дефинише имплицитни курикулум и да му не придаје исти значај заборављајући при томе да школа не служи само за преношење знања, већ активно учествује у обликовању родних и других идентитета, као и родних идеологија, што су уједно и основни теоријски постулати критичке педагогије на чијим идејама почива овај рад.

Кључне речи: имплицитни курикулум, родне идеологије, наставни кадар, шпански као страни језик.

\section{1. Увод}

На развој родног идентитета утичу различити чиниоци, а друштвене институције, као што су породица, школа, радно окружење и медији, уче нас како девојчице треба да се понашају - да буду брижне, док би дечаци требало другачије да де-

1 milica.djuricic@gmail.com 
Милица Ђуричић Гњатовић

лују, да буду јаки и независни (Холмс 2009: 3). Треба напоменути да се већина дискриминаторних облика понашања учи још у породици, јер је то прва институција друштва у којој се одвија социјализација, а школа кроз употребу језика, начина на који се преноси знање итд., односно са свим оним што са собом носи скривени курикулум, учвршћује родне стереотипе (Терон Каро и Кобано-Делгадо Палма 2008: 385, 386). У оквиру школе ученицима и ученицама преносе се ставови и вредности путем текстова и кроз дискурс наставног кадра. Најчешће су у питању вредности и идеологије које се прихватају као природне и дате.

Управо из тог разлога определили смо се да испитамо да ли је наставном кадру познат термин имплищитни курикулум, као и његове евентуалне последице на развој родних и језичких идеологија ђака, те се у овом раду бавимо анализом ставова наставника и наставница према скривеном курикулуму у настави шпанског као страног језика у Србији, посебно када је реч о употреби оба граматичка рода у настави, што директно корелира и са промовисањем идеја о родној равноправности и родно осетљивом језику у настави. Пре навођења и коментарисања резултата истраживања, дајемо кратак преглед основних теоријских постулата критичке педагогије, на чијим идејама базирамо овај рад. Поред тога, наводимо какав утицај може имати школа у преношењу родних идеологија, затим дефинишемо кључни термин овог рада, а то је појам скривеног, односно имплицитног курикулума.

\section{2. Критичка педагогија}

Један од главних представника критичке педагогије, Паоло Фреире (Paolo Freire), напомињао је да образовање треба да пружи могућности за развој способности за самопреиспитивање, управљање сопственим животом и критичко деловање (Милутиновић 2016: 95). У питању је приступ који покушава да помогне ученицима и ученицама да преиспитају доминант- 
на веровања и праксе са циљем да се код њих развије критичка свест и да им се тако помогне да постану активни носиоци друштвене промене (Риасати и Молајеи 2012: 224; Нортон и Туи 2004: 3). Дакле, ученици и ученице, према критичкој педагогији, јесу активни учесници и учеснице у процесу наставе, али и у друштву (Риасати и Молајеи 2012: 224). Наиме, они нису само пасивни примаоци знања, већ имају активну улогу у његовој конструкцији (Милутиновић 2016: 113), а наставници и наставнице, према идејама критичке педагогије, требало би да имају развијене компетенције за самоиспитивање уверења и деловања, али и за преиспитивање друштвеног контекста у ком живе и раде (Милутиновић 2015, према Милутиновић 2016: 105). Међутим, наставници и наставнице би и сами требало да преиспитају своје претпоставке и уверења, „као и хегемонистичких аспеката доминантних културних вредности“ (Милутиновић 2016: 109). Критички феминистички приступи наставни кадар могу нагнати на преиспитивање сопствених претпоставки и до проблематизовања њихових свакодневних пракси, а могу и ђаке навести на преиспитивање сопствених језичких избора, понашања и слично развијањем критичке свести (Kramsh \& von Hoene 2001, према Павленко 2004: 55, 56), што се уједно жели показати овим радом у ком се наставни кадар који предаје шпански као страни језик у основним и средњим школама у Србији посматра као делатна заједница која може имати утицаја на развој критичке свести код својих ученика и ученица о питању родне равноправности и употребе родно сензитивног језика како у српском као матерњем тако и у шпанском као циљном језику.

Између осталог, наставник или наставница страног језика требало би да повезује знања граматике и вокабулара са знањем о друштвеним проблемима и начина на који би се они могли решити (Риасати и Молајеи 2012: 224). Дакле, задатак наставног кадра није само преношење знања из одређених области, већ је реч о много комплекснијим задацима, који се односе и на подизање критичке свести код ученица и ученика о доминантним идеологијама, културним моделима и 
Милица Ђуричић Гњатовић

установљеним обрасцима понашања. Но, питање је да ли су наставници и наставнице уопште свесни постојања скривеног курикулума и начинима на који се он манифестује. Управо у томе и лежи мотивација за спровођење овог истраживања.

\section{3. Улога школе у преношењу родних идеологија}

Недвосмислено је да је школа важан агенс социјализације. Међутим, социјални развитак појединца не почиње у школи, већ у породици. У школи се он систематски продужује (Јарић и Јарић 2013: 8). Дечаци и девојчице од најранијег узраста васпитавају се у правцу који би испунио захтеве и очекивања друштва на основу њиховог пола (Морено Санћес 2000: 12). Упркос променама улоге жене у друштву, у породици се и даље преносе модели који жену остављају у приватном домену, а мушкарцима намењују јавни домен (Морено Санћес 2000: 12). Породични модели и модели који се пласирају кроз медије представљају два кључна извора стереотипа и предрасуда. Школа, такође, може бити један од извора како експлицитним тако и имплицитним курикулумом (Ринц-Урошевић 2006: 321).

Међутим, школа сама по себи не производи родне моделе, већ она преноси шири, дубљи и слојевитији социјални контекст у ком постоји неравномерна расподела друштвене моћи на штету жене (Лер Софронић 2004: 21). Према томе, родна дискриминација не потиче из школе него се заснива на друштвеном и историјском конструисању социјалних улога које се додељују мушкарцима и женама. Школа је одраз онога што се у друштву, чији је саставни део, већ јавља. Стога, она није изоловани ентитет, већ је део културног и друштвеног система (Санћес Бељо 2002: 95). Образовни систем је, дакле, само једна у низу друштвених структура која производи и репродукује родне неједнакости, тј. неравномерну родну расподелу моћи у друштву и може бити једно софистицирано средство за репродукцију успостављених родних односа (Лер Софронић 2004: 20, 21). 
СКРИВЕНИ КУРИКУЛУМ У НАСТАВИ ШПАНСКОГ КАО СТРАНОГ ЈЕЗИКА...

Институције су у центру пажње истраживача и истраживачица, јер имају велику улогу у продукцији и ширењу дискурса који промовишу доминантне идеологије на уштрб маргинализованих група, попут расних, етничких мањина, припадника нижих класа, деце, жена (Буколц 2003: 57). Одређени односи моћи који постоје у сваком друштву рефлектују се у образовном систему (Торес 2005: 13). Ковачевић $(2010: 79,80)$ образовни систем види као најутицајнију институцију културе у преношењу патријархалних модела понашања, јер се путем њега како мушкарци тако и жене уче да прихватају друштвене улоге засноване на роду. Директно и индиректно исказивање родних стереотипа у овим оквирима може имати далекосежне последице и по жене и по мушкарце када је реч о одабиру будуће професије, улоге у друштву, у породици; може утицати на начин поимања света, а самим тим и на формирање слике о друштвено прихватљивим и неприхватљивим облицима понашања која се везују за девојчице, односно за дечаке. Међутим, образовни систем може деловати и у супротном правцу. Наиме, Стјепановић Захаријевски и др. (2010: 9) образовни и васпитни систем виде као кључан фактор у процесу преношења идеја о родној равноправности на млађе генерације. „Образовање, његови садржаји и праксе представљају моћне инструменте за репродукцију родних односа, али су истовремено и кључни механизми друштвених промена" (Стјепановић Захаријевски и др. 2010: 9). Према томе, васпитно-образовни контекст има велику улогу у продубљивању, поспешивању, али и промени и разбијању стереотипа било које врсте, па и стереотипа о роду.

Из свега наведеног следи да је неопходно вршити истраживања која би указала на проблематична питања нашег друштва када је реч о родној равноправности. Исто тако, од велике је важности подизати свест о овом питању код оних који имају директног утицаја на развој родних и других идеологија код чланова и чланица друштва, а то су наставници и наставнице. Управо су то и главни циљеви овог рада.

„Да би се постигла родна равноправност у образовном систему, од круцијалне је важности да се превазиђе и елиминише 
Милица Ђуричић Гњатовић

стереотипизација улога према полу. Образовна једнакост захтева наставни план и програм у коме нема дискриминаторних садржаја, родно сензитивни уџбеник и родно сензитиван приступ у настави“ (Ковачевић 2010: 69).

Међутим, родну дискриминацију у наставном процесу и у савременом друштву није увек једноставно уочити, јер, род изгледа природно дат, те веровања у вези са њим чине се као очигледна истина. Шевкушић (2011: 226) наглашава да је све оно што је изражено експлицитно у образовном процесу од мањег значаја у односу на имплицитна културална правила о томе како и чему се деца и адолесценти подучавају указујући на то шта се сматра важним, нормалним, правилним, друштвено прихватљивим итд. у датој заједници. Прикривене поруке које нам се пласирају путем средстава масовне комуникације, путем уџбеника, наставних планова и програма, дискурса наставног кадра и сл. посебно је тешко открити, те наредно поглавље посвећујемо управо појму скривеног, тј. имплицитног курикулума, и његовом значају у преношењу идеологија, пре свега, родних.

\section{4. Скривени курикулум}

„Скривени курикулум“ је термин који је први пут употребио педагог Џексон (Jackson) у својој књизи Живот у учионицама (Life in Classrooms) 1968. године (Нијето Бедоја 1991: 75). Он се може дефинисати на неколико начина, нпр. може се одредити као скуп садржаја који се имплицитно преносе у образовном контексту (Акасо и Нуере 2005: 208). Поменути облик курикулума може подразумевати скуп правила који наставници и наставнице подразумевају да ђаци познају иако нису подучавани о томе (Кониецка 2013: 251). Торес Сантоме (Torres Santomé) скривени курикулум дефинисао је као јачање знања, вредности и очекивања која су у складу са потребама и интересима хегемоне идеологије у датом друштвено-историјском контексту (Torres Santomé 1991: 198, према Ангуло Бланко 2010). 
СКРИВЕНИ КУРИКУЛУМ У НАСТАВИ ШПАНСКОГ КАО СТРАНОГ ЈЕЗИКА...

То је начин на који се ђаци уче да буду добри грађани и грађанке и да следе друштвене норме (Кониецка 2013: 251). Дакле, скривеним курикулумом ученици и ученице подучавају се одређеним облицима понашања како би били прихваћени у школи и у друштву, што подразумева усађивање вредности, ставова и принципа (Кониецка 2013: 250). Он представља скуп знања и вредности које се кроз образовни систем преносе тиме што се одређене друштвене вредности формирају и учвршћују, а друге се негирају и блокирају; реч је о систему знања и уверења о друштвеним односима и културним вредностима који нису експлицитно приказани у курикулуму (Јарић и Јарић 2013: 21). Курикулумом се истичу и преносе знања која се сматрају друштвено релевантним, те се тако и у њему понављају дискриминаторне поруке које се проналазе и у друштву које их ствара. Но, оне се не приказују директно, већ имплицитно кроз курикулум, што за последицу има непреиспитивање родних улога које се приписују мушком и женском роду, а то отежава и њихову промену (Лопес Охеда 2007: 634).

Поменути курикулум игра важну улогу у стварању значења и вредности којих како наставници и наставнице тако и ђаци нису свесни (Торес 2005: 10), што поврђује и Петрић (2006: 18) следећим речима: „Овај вид учења није планиран курикулумом, тачније речено, обично је потпуно непланиран и често га они који планирају и изводе курикулум нису ни свесни“. Њиме се преносе различите вредности и идеологије којих неретко нисмо свесни, јер се одређени ставови прихватају као природни. На пример, често нисмо свесни родних стереотипа и улога који нам се кроз уџбеник и дискурс уџбеника намећу. Стога, може се закључити да скривени курикулум може укључивати различите облике дискриминације и он обично служи како би се одржао статус quо у друштвено-економској хијерархији (Кониецка 2013: 250). Према томе, главни циљ скривеног курикулума јесте одржање и пренос одређених знања на један имплицитан начин. Реч је о знањима које не би било пожељно експлицитно исказивати у дискурсу учионице, попут позиционирања моћи, истицања одређене друштвене класе, расе, рода, 
културе, религије у односу на неке друге (Акасо и Нуере 2005: 208). У овом раду скривени курикулум повезујемо са родном припадношћу, идејама родне равноправности и родне дискриминације.

Овај појам може се дефинисати и као скуп очекивања наставног кадра од својих ученика и ученица. Наиме, наставници и наставнице у наставу улазе за већ формираним ставовима и идеолошким багажом, те унапред могу имати дефинисана очекивања заснована на роду или обрнуто, уколико су током свог школовања стекли знања о значају родно осетљивог језика, родно осетљивог садржаја наставних материјала које користе и родно осетљивог приступа у настави, затим да је неопходан једнак третман свих ђака без обзира на њихов биолошки пол или припадност некој групи (расној, етничкој, родној итд.). Према томе, наставници и наставнице својим деловањем могу позитивно утицати на развој критичке свести о питањима рода код својих ученика и ученица, чиме се детаљније бавимо у наставку овог рада.

\section{1. Скривени курикулум и родне идеологије}

Када је у питању разлика између експлицитног и имплицитног/скривеног курикулума у погледу рода, први је више у складу са тенденцијом постојања равноправности између мушкараца и жена у односу на други (Љорент-Бедмар и Кобано- Делгадо Палма 2014: 171).

За испитивање скривеног курикулума као методолошки оквир погодна је и критичка анализа дискурса која испитује како оно што је у дискурсу експлицитно исказано, тако и оно што је прећутано.

Може се извести закључак да још увек нису нестали стереотипи који утичу на понашање, одабир професије и очекивања базирана на основу рода. У данашње време верује се да је превазиђен било који вид дискриминације, но може се пронаћи скривени курикулум који одржава родну дискриминацију како у личним односима међу припадницима мушког и 
СКРИВЕНИ КУРИКУЛУМ У НАСТАВИ ШПАНСКОГ КАО СТРАНОГ ЈЕЗИКА...

женског рода, тако и у дидактичком материјалу (Лопес Охеда 2007: 631), што је уједно и једна од хипотеза овог рада.

Скривени курикулум преноси се кроз усмени и писани дискурс као и путем илустрација (Акасо и Нуере 2005: 209). Стога је све поменуте елементе неопходно узети у разматрање приликом анализе родно осетљивог садржаја уџбеника. Но, како смо раније напоменули, наставници и наставнице својим деловањем, такође, могу, свесно или несвесно, преносити идеје скривеног курикулума.

Критичко проматрање сексизма у уџбеницима, као и испитивање ставова и мишљења наставног кадра према поменутој тематици један је од основних циљева овог рада, а подразумева анализирање идеолошке димензије скривеног курикулума.

„Класичан пример скривеног курикулума односи се на суптилне разлике у третману ученика и ученика у традиционалној школи, у којима многи на први поглед неће уочити ништа неуобичајено. На пример, дечаци и девојчице у уџбеницима често су представљени, како визуелно, тако и кроз дијалоге, тако да припадају различитим сферама активности, што се онда посредно преноси ученицима као родно заснован модел понашања" (Петрић 2006: 18).

Курикулум не показује друштвену стварност коју данас проживљавају како жене тако и мушкарци у професионалном и приватном домену игноришући постојање самохраних родитеља, хомосексуалних парова итд. (Морено Санћес 2000: 25). Скривени курикулум у шпанском контексту заснива се на преносу знања заснованих на капиталистичком патријархалном систему, што укључује и доминацију мушког у односу на женски род (Акасо и Нуере 2005: 208, 209). Исти закључак може се односити и на српски образовни систем, јер постоји јасна паралела између шпанског и српског друштва по питању ставова о роду, родним улогама и родно сензитивном језику (в. детаљније Ковачевић 2010; Јарић и Јарић 2013; Петрић 2006; Филиповић 2010).

Садржај курикулума готово увек у скаду је са доминантном идеологијом, јер он увек бива одобрен од стране државних ин- 
Милица Ђуричић Гњатовић

ституција, попут Министарства просвете (Коларић 2008: 161). Ова тврдња може се тицати и уџбеника који се користе у државним школама, пошто они, такође, бивају одобрени од Министарства просвете, а користе их наставници и наставници у нашим основним и средњим школама.

\section{5. Истраживање}

\section{1 Мотивација, циљеви и хипотезе}

Истраживања у вези са сексизмом у настави страних језика, али и других школских предмета, у фокусу интересовања углавном су имала садржај наставних материјала. Том приликом неретко се заборавља на то да уџбеници сами по себи не могу утицати на промену или учвршћивање родних идеологија и родних стереотипа, већ је неопходно испитати и на који начин се одређени материјали и користе у учионици, било да је реч о сексистичким, било да је реч о несексистичким уџбеницима. Из тог разлога определили смо се за квалитативно истраживање како бисмо дошли до одговара на следећа питања: да ли је наставницима и наставницама познато шта се подразумева под термином скривени/имплицитни курикулум и уколико јесте, занима нас начин на који га дефинишу.

Ово истраживање спроведено је у периоду од новембра 2015. до маја 2016. године у оквиру рада на докторској дисертацији под називом „Критички приступ садржају уџбеника за шпански као страни језик у Србији са аспекта рода“. Наставном кадру електронским путем прослеђен је упитник како бисмо, између осталог, стекли увид у то да ли је испитаницима и испитаницама познат један од кључних термина у области критичке педагогије, а то је појам скривеног/имплицитног курикулума. Осим тога, били смо заинтересовани на које начине наставни кадар дефинише поменути појам и да ли га доводи у везу са родном равноправношћу и родно сензитивним језиком. 
СКРИВЕНИ КУРИКУЛУМ У НАСТАВИ ШПАНСКОГ КАО СТРАНОГ ЈЕЗИКА...

Једна од хипотеза овог истраживања јесте да наставни кадар на различите начине оцењује уџбенике за шпански као страни језик по питању његовог родног садржаја, али и своју наставну праксу, зависно од својих личних ставова, вредности, идеологија, упућености у дату тематику и сл., пошто припадници и припаднице једне друштвене заједнице не перципирају родне стереотипе на исти начин. Заправо, док код неких постоји развијена критичка свест о облицима у којима се родна неравноправност може јавити, други могу родне стереотипе прихватати као здраворазумску истину и сматрати да нема потребе преиспитивати и мењати дискриминаторне друштвене односе и праксе, пошто их уопште не поимају као такве.

\section{2 Испитаници и испитанице}

У овом квалитативном истраживању учествовало је укупно тридесет и пет наставника и наставница шпанског језика који изводе или су некада током своје наставне праксе изводили наставу у основним и средњим школама у Србији.

За потребе овог истраживања нису нам били важни нити биолошки пол нити године радног искуства, јер поменуте варијабле, по нашем мишљењу, не корелирају директно са промовисањем идеја о родној равноправности у учионици, нити са критичким проматрањем скривеног курикулума.

\section{3 Резултати истраживања}

Нешто мање од половине испитаника и испитаница, њих четрнаесторо, навело је да им није познато шта термин скривени курикулум означава. Било је и оних који су напоменули да до овог упитника нису знали шта је скривени курикулум, али су потражили одговор на интернету.

Остали наставници и наставнице написали су следеће: „Можда означава вредност и битност онога што ученици стекну и науче у школама, јер све оно што стекну ту, касније ће примењивати у животу“; „Претпостављам да су то нека знања и 
Милица Ђуричић Гњатовић

ставови који се провлаче кроз редовни наставни план и програм на неки 'невидљив' начин, а које ученици усвајају несвесно“; „Рекао бих да се односи на васпитне и функционалне циљеве који се остварују у настави тј. на све оно што ученици усвајају на часу осим градива. Реч је о ставовима, судовима, вредностима, вештинама које развијају“; „Курикулум подразумева наставни план и програм рада, док би се скривени курикулум односио на знање које се стиче, учвршћује или формира под утицајем тог званичног програма. Одређене културне или социјалне вредности се на тај начин могу блокирати или учврстити“; „Претпостављам да су у питању идеје или ставови који се провлаче кроз лекције и вежбања, а који треба да утичу на начин виђења стварности или неке појаве код ученика“.

Има испитаника и испитаница који су термин скривени курикулум повезали са улогом наставника и наставница у образовном процесу, што је уједно и једна од централних идеја овог рада, али и једна од основних поставки критичке педагогије. Њихове одговоре истичемо у наставку: „То су неке социјалне и етичке вредности које ученици усвајају путем материјалних средстава која им обезбеђују наставници и школа, међу којима су и ставови који се тичу родне равноправности“; „Оно што наставник сматра релевантним, а није експлицитно речено у наставном плану и програму“; „Мислим да је то оно што научимо ученике мимо планираног школског курикулума, а односи се на формирање животних ставова и критичког мишљења“; „Ставови, убеђења, вредности које ученици усвајају у школи већим делом од наставника“; „Материјал који ученици несвесно науче у школи. Има негативан тон, указује на неједнакост коју наставници пренесу ученицима (начин на који причају о нпр. ратовима, култури...)“; „Оно што ученици усвајају од нас наставника (понашање, ставови...), а да ми нисмо ни свесни да их преносимо на њих“; „Скривени курикулум представља вредности које се ученицима/ученицама намећу кроз школски систем. Претпостављам да се овај термин односи на наметање родних идеологија од стране предавача и образовног система, и то пре свега путем одабира одређених уџбеника и 
СКРИВЕНИ КУРИКУЛУМ У НАСТАВИ ШПАНСКОГ КАО СТРАНОГ ЈЕЗИКА...

начина њиховог коришћења у настави“; „Вредности које ученици усвајају индиректно кроз наставни материјал и интерпретацију истог од стране наставника, али не само њега, већ целокупног друштва, није експлицитно у плану и програму, али обухвата формирање друштвене свести, ставова и вредности кроз васпитно-образовни процес“; „Мислим да то представља све оне ставове, претпоставке, вредности које наставници уносе у сам образовно-васпитни рад на часу и у школи, а који на неки начин представљају каква је нека школа, какви су односи у њој и сл.“; „Вредности, веровања и знања која не улазе у евалуацију, у смислу да се не оцењују, а које ученици усвајају несвесно, кроз школовање и која зависе од начина на који им се наставни материјал пласира, од уџбеника и приручника који се користе у настави, од њиховог садржаја и ставова самог предавача. Сматрам да на креирање имплицитног курикулума у великој мери утичу и неке важне институције попут Министарства просвете и неких других образовних органа који у великој мери креирају начин извођења наставе и средства која ће се користити у настави“; „Представља вредности које ученици науче у школи (друштвене и полне улоге, ставови....) кроз начин на који је организована настава, кроз наставна средства која се користе, итд. Наставници имају велику одговорност, будући да су пре свега педагози. Срећом, на часовима страног језика може се дискутовати о свему и на тај начин подстицати ученике на размишљање и развијање правих вредности“.

\section{4 Коментар резултата истраживања}

Резултати су показали да нису сви наставници и наставнице упознати са термином скривени/имплицитни курикулум, премда то не значи да не разумеју суштински принцип који се њиме означава.

Сматрамо да је од велике важности да се код наставног кадра развије свест о томе да се путем дидактичког материјала који користе могу преносити имплицитне вредности друштва и културе у којима се настава одвија, али и заједнице у чијим је оквирима дати уџбеник настао. Осим тога, важно је указа- 
Милица Ђуричић Гњатовић

ти наставницима и наставницама да они сами својим дискурзивним праксама преносе вредности и идеологије, што може имати далекосежне последице на развој идентитета својих ђака, о чему је сведочила и једна испитаница која је сексизам у настави дефинисала као: „ограничавање у формирању ставова ученика, посебно оних млађих и подстицање да се мушки род усвоји као доминантнији у односу на женски“.

Неопходно је имати у виду да дидактичке и методичке компетенције нису довољне за успешно извођење наставе страних језика. Потребно је стећи знања о друштвеним, политичким, културолошким и контекстуалним аспектима наставе страних језика и имплементирати их у наставу (Филиповић и Јовановић 2013), што, свакако, подразумева спремност и отвореност наставног кадра за промене. Слажемо се да би наставници и наставнице својим деловањем требало „да утичу на формирање позитивних родних, културних, етничких и професионалних идентитета код својих ученика и ученица“ (Филиповић 2010: 57).

Можда би било претенциозно очекивати од наставника и наставница да се баве поменутом тематиком с обзиром на чињеницу да током свог школовања будући просветни радници и раднице не уче о начинима на који се скривени курикулум манифестује. Затим, нема стручних скупова на којима би се дискутовало о потреби родно осетљивих уџбеника и неопходности употребе родно сензитивног језика у образовном контексту на свим часовима без обзира о ком школском предмету је реч, што негативно утиче на развој критичке свести код наставног кадра о овој проблематици. Међутим, треба имати у виду да школа као институција не постоји само због преноса знања, већ има и васпитну улогу. Отуда, неоходно је барем на индивидуалном нивоу улагати напоре у развој критичке свести код ученика и ученица о важности употребе политички коректног језика. То није тема коју би требало занемарити иако, свакако, није једини проблем нашег друштва и образовања, али је питање коме треба посветити посебну пажњу у патријархалном друштву какво је српско. Један од циљева образовања 
СКРИВЕНИ КУРИКУЛУМ У НАСТАВИ ШПАНСКОГ КАО СТРАНОГ ЈЕЗИКА...

треба да буде пружање једнаких прилика свим учесницима и учесницама у том процесу без обзира на родну припадност, а један од начина јесте приказивање жене у различитим доменима друштва кроз језичке изборе који праве разлику између мушког и женског рода или који неутрализују ту разлику. Употребу мушког као генеричког рода не би требало сматрати прихватљивом ако се у обзир узме чињеница да је у нашој земљи у савременом друштву образовање доступно свима, како дечацима тако и девојчицама. Не би требало охрабривати младе људе да доносе стереотипне одлуке у вези са својом будућношћу, односно одабиром каријере и неразвијањем критичког става према патријархалним родним улогама, јер на тај начин бивају лишени шансе да се опробају у нечему што није типично за њихов род.

Упркос променама у законским регулативама које елиминишу дискриминацију, културни модели који се и даље нуде младим генерацијама кроз уџбенике настављају са приказивањем разлика у опхођењу према женама и мушкарцима, што отежава напоре професорског кадра да модификује односе између ученика и ученица и да нормализује слику жене у култури као и у пружању равноправних шанси за оба рода (Родригес Искијердо 1998: 259). Проблем се додатно усложњава уколико наставни кадар не препознаје дискриминаторне поруке које се пласирају кроз уџбеник, а неретко ни сами наставници и наставнице нису свесни својих идеологија и деловања који могу ићи у правцу даљег преноса родних стереотипа. Понекад је наставницима и наставницама потребно указати на која би питања требало да обрате пажњу и на који начин да им приступе у учионици како би исход школовања ђака био што бољи и у васпитном и у образовном смислу, што су показали и подаци прикупљени за потребе овог рада.

Овим истраживањем указали смо на неопходност развоја критичке свести о питању рода, родно сензитивног језика и родне равноправности код деце, адолесцената и младих, што, пре свега, захтева подизање критичке свести код наставног кадра, те предлажемо укључивање основних теоријских по- 
Милица Ђуричић Гњатовић

ставки у вези са поменутим појмовима у обавезан академски програм будућих наставника и наставница. Међутим, с обзиром на то да би се наставни кадар и после завршених студија константно требало усавршавати и развијати компетенције, сматрамо да је од велике важности организовати семинаре и конференције на којима би се говорило о утицају који целокупан образовни систем може имати на развој родних и других идентитета ђака, што недвосмислено може имати последице и по њихов одабир професије и друштвених улога уопште.

\section{6. Закључак}

Испитивање скривеног курикулума представља једно изузетно сложено питање у контексту српске културе која се перципира као традиционално патријархална у којој се и данас поједине друштвене структуре опиру променама ове врсте наглашавајући да постоје горући и важнији проблеми од проблема рода, али ово питање свакако завређује пажњу свих припадника и припадница наше заједнице, а промене на боље и на дуже стазе могле би отпочети управо у оквирима школског система.

Скривени курикулум може имати великог утицаја на развијање, одржање или промену идеологија код ученика и ученица, посебно зато што је реч о нечему чега најчешће нисмо ни свесни, већ нам се оно чини као природно и дато. Иако у двадесет и првом веку званични курикулум инсистира на родној равноправности, скривеним курикулумом на суптилан начин разлике се поспешују, што може утицати на формирање родног идентитета код ђака, а самим тим може имати утицаја на њихов одабир занимања и активности на основу родних улога које су прихватљиве за један, односно други род, у датом културном, друштвеном и историјском контексту, а што се и кроз уџбеник намеће, те је неопходно указати наставном кадру на који начин би требало да раде са ђацима како би промовисали идеје о родној равноправности и како би својим ђацима пружили подједнак третман без обзира на њихову родну припадност, која је ирелевантна за процес наставе. 

ЛИТЕРАТУРА

Акасо и Нyepe 2005: Acaso, M. \& S. Nuere. El currículum oculto visual: aprender a obedecer a través de la imagen. Arte, Individuo y Sociedad, 17, 205-218.

Ангуло Бланко 2010: Angulo Blanco, M. E. La evolución del papel de la mujer en dos manuales de ELE a través de las mujeres. RedELE: Revista Electrónica de didáctica del español como lengua extranjera, 12, 1-47. [online] [http://www.mecd.gob.es/dctm/redele/MaterialRedEle/Biblioteca/2011 BV 12/2011 BV 12 22Angulo.pdf?documentId=0901e72b80dbf384 приступљено 10. октобра 2015].

Буколц 2003: Bucholtz, M. Theories of Discourse as Theories of Gender: Discourse Analysis in Language and Gender Studies, In: J. Holmes \& M. Meyerhoff (Eds.), The Handbook of Language and Gender. Oxford: Blackwell, 43-68.

Јарић и Јарић 2013: Jarić, V. / I. Jarić. Rodna ravnopravnost u srednjem stručnom obrazovanju: stavovi i uloga srednjoškolskih nastavnika/ ica i stručnih saradnika/ica u unapređivanju rodne ravnopravnosti. Beograd: Deutsche Gesellschaft für Internationale Zusammenarbeit (GIZ), InDesigner.

Коларић 2008: Kolarić, A. Smeh i suze srpskog obrazovanja: rodni i etnički stereotipi u čitankama za srpski jezik i književnost u osnovnoj školi. Reč: časopis za književnost i kulturu, 76 (22), 153-192.

Ковачевић 2010: Ковачевић, К. Дидактичко-методичка анализа уџбеника у разредној настави са аспекта социјалне улоге пола. Педагошка стварност, 56 (1/2), 68-81.

Кониецка 2013: Konieczka, J. The Hidden Curriculum. Advanced Research in Scientific Areas, 250-252.

Лер Софронић 2004: Ler Sofronić, N. Mama kuha, nana plete...Ili sretan ti početak, đače: rodni stereotipi u osnovnom obrazovanju. U: Prevazilaženje rodnih stereotipa u osnovnom obrazovanju. Zbornik radova sa Regionalne strateške konferencije održane u Budvi 2. i 3. oktobra 2004. u organizaciji ŽNVO Ženska akcija, u okviru EastEast programa. Crna Gora: Foundation open society institute - predstavništvo Crna Gora, 17-26

Љорент-Бедмар и Кобано-Делгадо Палма 2014: Llorent-Bedmar, V. / V. Cobano-Delgado Palma. La mujer en los libros de texto de Bachillerato de España. Cadernos de Pesquisa. 44 (151), 156-175, [online], [http:// dx.doi.org/10.1590/198053142752 приступљено 12. априла 2016].

Лопес Охеда 2007: López Ojeda, E. Pautas de observación y análisis del sexismo. Los materiales didácticos. Interlingüística, 17, 630-639. 
Милица Ђуричић Гњатовић

Милутиновић 2016: Milutinović, J. Socijalni i kritički konstruktivizam u obrazovanju. Novi Sad: Filozofski fakultet [online], [http://digitalna.ff.uns.ac.rs/sadrzaj/2016/978-86-6065-355-2, приступљено 1. јуна 2016].

Морено Санћес 2000: Moreno Sánchez, E. La transmisión de los modelos sexistas en la escuela. En: M. A. Santos Guerra (coord.) et al., El harén pedagógico: Perspectiva de género en la organización escolar). Barcelona: Graó (2ª edición), 11-32.

Нијето Бедоја 1991: Nieto Bedoya, M. Los textos escolares transmisores de un curriculum oculto. Tabanque: Revista pedagógica, 7, 75-84.

Нортон и Туи 2004: Norton, B./ К. Toohey. Introduction. In: B. Norton / K. Toohey (eds.), Critical Pedagogies and Language Learning. Cambridge: Cambridge University Press: 1-15.

Павленко 2004: Pavlenko, A. Gender and Sexuality in Second and Foreign Language Education: Critical and Femist Approaches. In: B. Norton \& K. Toohey (Eds.), Critical Pedagogies and Language Learning. Cambridge: Cambridge University Press: 53-71.

Петрић 2006: Petrić, B. (2006). Rečnik reforme obrazovanja. Novi Sad: Platoneum; Misao; Pedagoški zavod Vojvodine.

Риасати и Молајеи 2012: Riasati, M. J./ F. Mollaei. Critical Pedagogy and Language Learning. International Journal of Humanities and Social Science, 2 (21), 223-229.

Ринц-Урошевић 2006: Rinc-Urošević, A. Uticaj polnih stereotipa na vaspitanje i obrazovanje. Pedagogija, 61 (3), 320-330.

Родригес Искијердо 1998: Rodríguez Izquierdo, R. M. La imagen y el papel de la mujer en los libros de texto escolares en España. Escuela abierta I, 257-265.

Санћес Бељо 2002: Sánchez Bello, A. El androcentrismo científico: el obstáculo para la igualdad de género en la escuela actual. Educar, 29, 91-102.

Стјепановић Захаријевски и др. 2010: Stjepanović Zaharijevski, D. i dr. Obrazovanje za rodnu ravnopravnost: analiza nastavnog materijala za osnovnu i srednju školu. Beograd: Program Ujedinjenih nacija za razvoj.

Терон Каро и Кобано-Делгадо Палма 2008: Terrón Caro, M. T./ V. Cobano-Delgado Palma. El papel de la mujer en las ilustraciones de los libros de texto de educación primaria. Foro de Educación, 10, 385-400. Topec 2005 [1995]: Torres, J. El curriculum oculto. Madrid: Morata.

Филиповић 2010: Филиповић, J. Род, језик и родно осетљиве језичке политике. У Ј. Филиповић и др. (ур.), Округли сто на тему родно осетљивих језичких политика. Београд: Програм Уједињених нација за развој, Сектор за инклузивни развој, 15-73. 
СКРИВЕНИ КУРИКУЛУМ У НАСТАВИ ШПАНСКОГ КАО СТРАНОГ ЈЕЗИКА...

Филиповић и Јовановић 2013: Filipović, J./A. Jovanović. Spanish Teacher Education Programs and Community Engagement. Hispania, 96 (2), 283-294.

Холмс 2009: Holmes, M. Gender and Everyday Life. The New Sociology. London, New York: Routledge.

Шевкушић 2011: Шевкушић, С. Квалитативна истраживања у педагогији. Допринос различитих методолошких приступа. Београд: Институт за педагошка истраживања.

\title{
ПРИЛОГ
}

\section{Примерак упитника}

Да ли знате шта се подразумева под термином „скривени/ имплицитни курикулум“? Молим Вас образложите.

\section{Milica Đuričić Gnjatović}

\section{HIDDEN CURRICULUM IN TEACHING SPANISH AS A FOREIGN LANGUAGE IN SERBIA WITH PARTICULAR REFERENCE TO GENDER SENSITIVE APPROACH IN THE CLASSROOM: TEACHERS' ATTITUDES}

\begin{abstract}
Summary
Educational institutions convey dominant social ideologies, and it is important to take a critical attitude towards what is happening in the classroom. It is necessary to analyze both the explicit and the implicit curriculum. For this reason, we have decided to analyze Spanish teachers'
\end{abstract}


attitudes towards the concept of hidden curriculum and the way they define it with a special emphasis on gender sensitive teaching approaches. A questionnary has been sent to Spanish teachers in Serbia.

After a qualitative analysis, we have come up with results that indicate that the teaching staff defines the implicit curriculum in different ways and does not attach the same importance to it, while forgetting that the school does not only serve to transfer knowledge, but also actively participates in the formation of gender and other identities, and gender ideologies, which are at the same time the basic theoretical postulates of critical pedagogy on whose ideas this work is based.

Key words: gender ideologies, implicit curriculum, Spanish as a foreign language, teaching staff. 